\title{
XLVI. Account of a remarkable meteor, seen December 19, 1849
}

\section{Professor J.D. Forbes}

To cite this article: Professor J.D. Forbes (1850) XLVI. Account of a remarkable meteor, seen December 19, 1849, Philosophical Magazine Series 3, 37:251, 357-363, DOI:

$10.1080 / 14786445008646628$

To link to this article: http://dx.doi.org/10.1080/14786445008646628

册 Published online: 30 Apr 2009.

Submit your article to this journal $\lceil\pi$

Џ Article views: 2

Q View related articles $\asymp$ 
XLVI. Account of a remarkable Meteor, seen December 19, 1849. By Professor J. D. Formes*.

$\mathrm{O}^{\mathrm{N}}$ N the evening of the 19th December 1849, whilst walking near the southern part of Edinburgh, about fifteen minutes past five, Greenwich time (as I afterwards estimated), I observed a meteor, fully brighter than Venus at her average brilliancy, moving from W. towards $\mathrm{N}$., parallel to the horizon, elevated $15^{\circ}$ above it, and followed by a distinct luminous train. This angle was subsequently taken by estimation by daylight, with the aid of a theodolite; and the compass-bearing of the meteor, when first seen, ascertained in the same way, must have been $47^{\circ} \mathrm{W}$. of $\mathrm{N}$. When it bore $29^{\circ} \mathrm{E}$. of magnetic north, it was observed to have divided into two, the one part following the other at some distance; and I soon after lost sight of it in the obscurity of the smoke of the town. When it split, its altitude was estimated at $6^{\circ}$. It thus described an arc of no less than $76^{\circ}$, in doing which it occupied, as I roughly estimated, about fifteen seconds, or possibly more.

Having sent a short notice of the appearance of the meteor to the Courant newspaper, I received from many quarters accounts of its having been seen under circumstances remarkably similar to those just described. I believe that nearly forty communications on the subject have reached me from places included between Longford, in the centre of Ireland, to near Bervie in Kincardineshire, a distance of above 300 miles, in a direction nearly N.E. and S.W.; whilst in a perpendicular direction, or firom N.W. to S.E., the range of observation has been comparatively small; for I have received no information from beyond Renfiew in the one direction, and Durham in the other, being about 140 miles distant in a straight line. The meteor was seen at Longford, in Ireland, 74 miles west of Dublin, but not in Dublin itself. It was seen at Belfast, between Carlisle and Gretna at Stewarton in Ayrshire, at Johnstone, at Paisley, Renfrew, and by many persons in Glasgow and the neighbourhood. It was also generally seen in Edinburgh, in East Lothian, near Melrose, and at Durham, as already mentioned. Further north, I bave received accounts from Crail, St. Andrews, Dundee, Perth, and Johnshaven to the north of Montrose.

The greater number of these communications concur in estimating the direction of the motion of the meteor to have been from S.W. to N.E., although, as might be expected,

* From the Proceedings of the Royal Society of Edinburgh, vol, ii. No. 39. 
they vary excessively as to its distance and magnitude; being described by some persons as only 50 or 100 yards off, and as large as the moon; by others, as a ball of 9 inches in diameter, or the size of a large egg. One person only professes to have heard a sound. The time during which it was seen was variously estimated. At Longford, by Mr. Curtis, 20 seconds; at Glasgow, by Mr. Stevenson, at 20 seconds; at Johnstone, by Mr. Cunningham, 15 seconds; at Perth, 15 or 20 seconds; at Durham, by Mr. Carrington, 30 seconds; at St. Andrews, 15 seconds according to one observer, and 18 to 21 seconds according to another; at Johnshaven, $\frac{3}{4}$ ths of a minute. The hour of the appearance of the meteor, in most of the descriptions, is stated at between $5^{\mathrm{h}} 10^{\mathrm{m}}$ and $5^{\mathrm{h}} 16^{\mathrm{m}}$.

The arc of the horizon which it was seen to traverse depended, of course, on the point where the meteor first caught the observer's eye. At Granton, it was traced by Professor Kelland through $125^{\circ}$ of azimuth; at Perth, $130^{\circ}$; at St. Andrews, $74^{\circ}$; at Edinburgh, $76^{\circ}$; at Durham, $65^{\circ}$; at Glasgow, from $60^{\circ}$ to $70^{\circ}$. The division of the head or nucleus into several parts, and, first of all (in most cases), into trwo, has been noticed with remarkably slight variation; consequently, the explosion of the meteor marks a well-determined point in its path. The separation was specially noticed at Edinburgh, Granton, Glasgow, Renfiew, Melrose, Haddington, Johnshaven, Perth, Durham and St. Andrews.

In a majority of cases a luminous train was observed; and I am confident that the existence of this train, which has been estimated at from $2^{\circ}$ to $3^{\circ}$ long, cannot be questioned. Dr. Adamson, however, especially remarked that no train was to be seen at St. Andrews.

On revising the whole accounts, it does not appear that any of them can be relied upon for ascertaining the position of the meteor in space, except the observations of Mr. Carrington of the Durham observatory; of Professor Kelland, Mr. Stirling and nyself, at Edinburgh; of Dr. Adamson and another observer, communicated by Professor Fischer of St. Andrews; of a young gentleman at Perth, communicated by Thomas Miller, Esq., Rector of the Perth Academy; and of A. D. Stevenson, Esq., and W. Gourlie, Esq., jun., at Glasgow. My inquiries were chiefly directed to the two following points : first, the angular elevation of the meteor in the N.W. quarter of the heavens, where it is admitted by all that its path appeared almost horizontal; secondly, to the bearing of the meteor at the instant of explosion.

At Durham, Mr. Carrington saw the meteor first when the bearing was true N.W., the altitude (by theodolite) was then 
$10^{\circ}$, or not exceeding $11^{\circ}$; when it burst it was due N. (true), and continued to move $10^{\circ}$ or $12^{\circ}$ further before it disappeared. Professor Chevallier, who obligingly communicated these results, states that the meteor appeared rather to rise as it approached the north, but with a cloubt. 'This supposition, however, appears inadmissible, from the unanimity of the other accounts.

At Granton, near Edinburgh, Professor Kelland caught sight of the meteor a little to the $\mathrm{N}$. of the moon, and several diameters below it. This corresponds, by after estimation with a theodolite, to $75^{\circ} \mathrm{W}$. of magnetic N., and an altitude of $12^{\circ}$. Professor Kelland thinks that it rather rose afterwards. It split into two at $20^{\circ} \mathrm{E}$. of magnetic N., having then an altitude of only $5^{\circ}$; it continued for a considerable time bright, then began to fade, as if by the effect of distance, and also to separate into several parts : it was finally lost sight of $50^{\circ} \mathrm{E}$. of magnetic $\mathrm{N}$. (this bearing is well ascertained), with an altitude estimated at only half a degree. The position and circumstances of these observations, made at an elevated station above the Frith of Forth, were eminently favourable.

Mr. J. Stirling, civil engineer, looking up North Hanover Street, Edinburgh, saw the meteor separate into two parts; the bearing he afterwards estimated at $25^{\circ} \mathrm{E}$. of magnetic $\mathrm{N}$. (the probable error not exceeding $1^{\circ}$ ), and the altitude at $8^{\circ} 30^{\prime}$, certainly not exceeding $9^{\circ}$.

I think we may conclude, that at Edinburgh the meteor attained a maximum elevation of $15^{\circ}$ (that mentioned in the commencement of this paper), since it no doubt rose after Professor Kelland first saw it to the $\mathrm{S}$. of the true W., with an altitude of only $12^{\circ}$. The course of the meteor was evidently such as to be nearest the spectator when in the true N.W. or W.N.W.

The place of the meteor when it burst stands thus:-

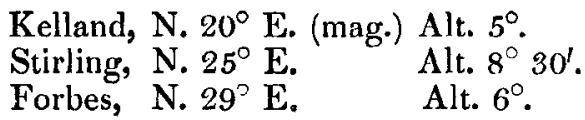

The average is almost $25^{\circ} \mathrm{E}$. of N., or about $1^{\circ} \mathrm{W}$. of the true meridian, the variation being nearly $26^{\circ}$. The mean of the three observations of altitude would be $6^{\circ} 30^{\prime}$; but admitting Mr. Stirling's to be entitled to the greatest confidence, we may suppose it $7^{\circ}$, or possibly a little more.

At St. Andrews, the meteor was seen by Dr. Adamson, when riding in a northerly direction on the Largo road. Professor Fischer was so kind as to accompany him afterwards to the spot, and to reduce his observations with all the accuracy 
of which they were capable. It was first noticed when bearing $8 \frac{1}{2}^{\circ} \mathrm{W}$. of magnetic N., and disappeared at $42 \frac{1}{2}^{\circ} \mathrm{E}$. of N.; the altitude was conjecturally stated as between $14^{\circ}$ and $18 \frac{1}{2}^{\circ}$, and it appeared to move horizontally, but rather declining towards the N.

After describing three-fourths of its course, it split into two parts, which went on close together for a little, then broke into four or five, became dull red, and rapidly disappeared; the separate pieces travelling on together until the last.

Another intelligent observer near St. Andrews, whose evidence was taken by $\mathrm{Mr}$. Fischer, first saw the meteor $293_{4}^{\circ} \mathrm{W}$. of magnetic $\mathbf{N}$., and estimated the point where the meteor burst at $44^{\circ} \mathrm{E}$. of $\mathrm{N}$; but this last number coincides so closely with Dr. Adamson's estimate of the point of final disappearance, that it is perhaps allowable to suppose, that this second observer had mixed up these two events in his description. Dr. Adamson's statement, that one-fourth of the arc which he saw was described after the meteor had split, would give an azinuth at that moment of almost $30^{\circ} \mathrm{E}$. of $\mathrm{N}$. magnetic, or $4^{\circ} \mathrm{E}$. of $\mathrm{N}$. true, as $\mathrm{Mr}$. Fischer determined the magnetic declination to be about $25^{\circ} 46^{\prime}$. The altitude of the meteor, as seen by this observer, appears not to have exceeded $15^{\circ}$ (the same as at Edinburgh); which number we shall therefore adopt.

At Perth, the passage of the meteor was seen from the North Inch, by a young gentleman of intelligence, whose ob. servations were reduced to numbers by $\mathrm{Mr}$. Miller, Rector of the Perth Academy, who was so good as to accompany him to the spot, and take the angles with a theodolite. Its bearing, when first seen, was $46^{\circ} \mathrm{S}$. of $\mathrm{W}$. true; its angular altitude was at that time only $3^{\circ} 30^{\prime}$. This is by far the most southeru azimuth which has been observed. Its bearing, when it disappeared, was $6^{\circ} \mathrm{W}$. of $\mathrm{N}$., but it was then lost in a cloud. If I understand right, it had by this time separated into fragments. Its apparent altitude in the middle of its course was about $17^{\circ} 30^{\prime}$. These observations, extending over an arc of $130^{\circ}$, taken along with Professor Kelland's, clearly demonstrate that the meteor appeared with a very low altitude in the S.W. quarter of the heavens, and disappeared in a similar way in the N.N.E., attaining its greatest elevation about W.N.W. (true).

At Glasgow the meteor was very generally and well seen. Mr. William Gourlie, jun., saw it move from S.W. to N.N.E., over an arc of $60^{\circ}$ or $70^{\circ}$, and divide into two, when it bore $40^{\circ} \mathrm{E}$. of magnetic $\mathrm{N}$. He estimates its greatest elevation at $30^{\circ}$; and that it decreased to between $15^{\circ}$ and $17^{\circ}$, or even 
less at the time of its separation: he adds, that he is not much accustomed to such observations. Mr. A. D. Stevenson, living in South Portland Street, Glasgow, saw the meteor moving along at a height just sufficient to clear the chimneytops, on the west side of the street; an elevation which he afterwards estimated, as he states, with considerable accuracy at $28^{\circ}$. I have received further and more minute accounts of the appearance of the meteor from Mr. Stevenson, who has been most kind and intelligent in his communications; and my friend Mr. James Peddie has verified the accuracy of Mr. Stevenson's observations beyond the possibility of mistake. It appears that the meteor passed quite clear of a stack of chimneys on the opposite side of the street, which would give it a well-defined minimum altitude of $25^{\circ} 41^{\prime}$; but $\mathrm{Mr}$. Stevenson is of opinion that it rose more than $2^{\circ}$ higher, or to not less than $28^{\circ}$ (perhaps even to $28^{\circ} 21^{\prime}$ ); when it was highest, its bearing was $52 \frac{1}{2}^{\circ} \mathrm{W}$. of $\mathrm{N}$. (magnetic), and it disappeared from his view when it bore $40^{\circ} 27^{\prime}$ E. of magnetic N. It roas then decidedly single. Now this bearing coincides with that at which $\mathrm{Mr}$. Gourlie observed it to become double, and consequently the limit towards the $\mathrm{N}$. of this event is severely defined.

The following table contains the most definite of these observations, and the azimuths are all reduced to the true meridian.

\begin{tabular}{|c|c|c|c|c|c|c|}
\hline & $\begin{array}{l}\text { Greatest } \\
\text { altitude. }\end{array}$ & $\begin{array}{l}\text { True azi- } \\
\text { muth when } \\
\text { first seen. }\end{array}$ & $\begin{array}{c}\text { True azimuth } \\
\text { of disappear- } \\
\text { ance. }\end{array}$ & $\begin{array}{c}\text { Arc } \\
\text { observed. }\end{array}$ & $\begin{array}{c}\text { True azimuth } \\
\text { of first ex- } \\
\text { plosion. }\end{array}$ & $\begin{array}{l}\text { Altitude } \\
\text { at first } \\
\text { explosion. }\end{array}$ \\
\hline $\begin{array}{l}\text { Durham .... } \\
\text { Edinburght } \\
\text { St. Andrews } \\
\text { Perth ...... }\end{array}$ & $\begin{array}{l}10030 \\
15 \\
15 \\
1730\end{array}$ & $\begin{array}{l}\mathrm{N} .45^{\circ} \mathrm{W} . \\
\mathrm{W} .11^{\circ} \mathrm{S} . \\
\mathrm{N} .55^{\circ} \mathrm{W} . \\
\mathrm{W} .47^{\circ} \mathrm{S} .\end{array}$ & $\begin{array}{l}\text { N. } 12^{\circ} \mathrm{E} . \\
\text { N. } 24^{\circ} \mathrm{E} . \\
\text { N. } 16^{\circ} \mathrm{E} . \\
\text { N. } 7^{\circ} \mathrm{W} . \\
\text { (in a cloud) }\end{array}$ & $\begin{array}{r}57 \\
125 \\
71 \\
130\end{array}$ & $\begin{array}{l}\text { N. } \\
\text { N. } 1^{\circ} W . \\
\text { N. } 4^{\circ} \mathrm{E} . \\
?\end{array}$ & 7 \\
\hline Glasgow ... & 28 & $\cdots \ldots$ & ........... & $100 ?$ & N. $14^{\circ} \mathrm{E}$ & 15 \\
\hline
\end{tabular}

\section{Remarks on the Observations.}

1. On the whole, these observations are not consistent, and cannot (I conceive) be cleared up without additional and accurate ones, which it may now be too late to procure. The central group of stations, Edinburgh, Perth and St. Andrews, are sufficiently accordant, and indicate that the path of the meteor must have been nearly parallel to a line passing through the first and last of those places, or in a direction N. $27^{\circ} \mathrm{E}$. (true); which accords well with the observations at most of the individual stations, and particularly with the va- 
nishing direction in Professor Kelland's remarkable observation at Granton.

2. The Durham observation is compatible with the abovementioned group within the limits of error. By the combination of Durham and Edinburgh (the base line perpendicular to the assumed direction of the meteor's motion being ninetyfive miles), I calculated that the meteor passed vertically nearly over the Island of St. Kilda, with an absolute elevation of about eighty-eight miles. But this solution seems absolutely excluded by observations at Glasgow which admit of no question, and which I have spared no pains in verifying. Had the position of the meteor been such as I have first assumed, it could not possibly have been seen over even the roofs of the houses from the station occupied by Mr. Stevenson, much less over the chimney-tops. The bearing at the moment of explosion at Glasgow, also singularly enough corroborates sufficiently well the comparatively small elevation (about twenty miles above the earth) which the combination of Edinburgh and Glasgow gives; and this bearing we have seen to have been also accurately defined by the physical obstacles bounding the observer's view; it would have given a parallax of $15^{\circ}$, subtended by the perpendicular on the meteor's path, referred to Glasgow and Edinburgh respectively. Now, if this calculation were anything like correct, the Perth observation is entirely wrong; and the meteor could not have risen about $6^{\circ}$ above the horizon of 1 )urham, instead of $10^{\circ}$ or $11^{\circ}$ as estimated. I am unable in any degree to explain these conflicting results.

3. The observations of Professor Kelland at Granton, and those at Perth, through the great azimuths of $125^{\circ}$ and $130^{\circ}$, described by the meteor with such remarkable deliberation of motion, lead, when analysed, to the very same results which presented themselves to the mind of the spectator intuitively; namely, that the motion must have been sensibly rectilinear, equable, and parallel to the horizon at Edinburgh. Assuming that the greatest altitude at Edinburgh was $15^{\circ}$, and the bearing then $\mathrm{N} .63^{\circ} \mathrm{W}$. (true), we may calculate that the altitude should have been on this hypothesis, when first seen by Professor Kelland, $11^{\circ} 47^{\prime}$, instead of $12^{\circ}$ as observed; at explosion, $6^{\circ} 59^{\prime}\left(7^{\circ}\right.$ observed), and at its final disappearance $0^{\circ} 47^{\prime}$ (instead of $0^{\circ} 30^{\prime}$ observed). Again, at Perth, the observed altitude, when first seen, was $3 \frac{1}{2}^{\circ}$, and the calculated altitude $5^{\circ} 3^{\prime}$, taking the maximum altitude at $17 \frac{1}{2}^{\circ}$. The coincidence is, on the whole, remarkable; though it would be rash to push it to an extreme, as an error of some degrees may exist in the assumption of the direction of the meteor's 
course. Some later observations, received fiom Mr. Curtis at Longford, and a consideration of the effects of perspective at Perth and Edinburgh, incline me to admit that the path might make an angle $3^{\circ}$ or $4^{\circ}$ greater with the meridian than I have above supposed. These conclusions are independent of the actual distance or parallax of the meteor; which, as I have said, cannot be determined without further observations, which I should be glad to receive from any quarter, but more particularly from lreland, and from the centre and N.W. of Scotland. If correct, they entitle us to infer that the meteor in question was most probably a body moving in space, in a path little curved, and not revolving round the earth.

XLVII. Additions to the articles in the September Number of this Journal, "On a new Class of Theorems," and on Pascal's Theorem. By J. J. Sylvester, M.A., F.R.S.*

FIRST addition.-I have alluded in the above article to a more general theorem, comprising, as a particular case, the theorem there given for the simultaneous evanescence of two quadratic functions of $2 n$ letters, or $n$ linear equations becoming instituted between the letters.

In order to make this generalization intelligible, I must premise a few words on the Theory of Orders, a term which I have invented with particular reference to quadratic functions, although obviously admitting of a more extended application. A linear function of all the letters entering into a function or system of functions under consideration I call an order of the letters, or simply an Order. Now it is clear that we may always consider a function of any number of letters as a function of as many orders as there are letters; but in certain cases a function may be expressed in terms of a fewer number of orders than it has letters, as when the general characteristic function of a conic becomes that of a pair of crossing lines or a pair of coincident lines, in which event it loses respectively one and two orders, and so for the characteristic of a conoid becoming that of a cone, a pair of planes or two coincident planes, in which several events, a function of four letters, becomes that of only three orders, or two orders, or one order, respectively. When a function may be expressed by means of $r$ orders less than it contains letters, I call it a function minus $r$ orders. I now proceed to state my theorem.

Let $\mathrm{U}$ and $\mathrm{V}$ be functions each of the same $m$ letters, and

* Communicated by the Author. 